\title{
MAMMALS
}

\section{'PILLORIED' MOOSE IN PRINCE ALBERT NATIONAL PARK, SK}

\author{
ELISABETTA TOSONI, Via Rubicone 16, Rome, Italy, 00198
}

Throughout the winter of $2002-2003$, Gudrum Pflueger and I monitored by ground tracking the movements of a pack of Grey Wolves in Prince Albert National Park. This pack has a core area that includes Waskesiu Lake in the southern Boreal Plains ecozone and is referred to as the 'Waskesiu Pack.'

The pack consists of 10 or 11 animals. We found that it routinely splits into two groups, one consisting of three animals and the other of seven or eight. These two units often pursued and killed prey independently, however, we also found that they coalesced on occasion. Tracks left on snow allowed us to assess the wolves' hunting strategies. These wolves often chased and killed deer and elk on the lake's frozen surface.

At 5:00 PM on March 18, 2003, I was conducting a survey of wolf tracks and scats along the shore of Waskesiu Lake near the Waskesiu marina. I was surprised to spot three members of the pack feeding on a carcass of a white-tailed deer on the ice near the marina. I observed the wolves for another half hour until darkness. Individual wolves were alternately resting, stretching their legs, or playing with other pack members. These could be considered normal behaviours for a wolf pack.

At 7:00 PM that evening, other wolves, which I suspected were the remaining eight members of the pack, started howling from the direction of South Bay on Waskesiu
Lake. Howling is an important means of long-range communication among wolves. The three wolves at the Marina immediately stood up and howled back. The howling session went on for 20 minutes. Then, there was absolute silence again. This was an amazing experience for me!

Early the next morning, I visited South Bay with Nahanni, my hairy, four-legged research partner, a domestic canid. There, I found tracks in the snow of the three wolves that I'd seen the evening before. They had crossed the Narrows Road about $100 \mathrm{~m}$ from its junction with Mud Creek Trail. The tracks led me to the lake where I noticed the tracks of the remaining eight wolves.

I did not want to disturb the animals so I decided to backtrack on the trail of the eight wolves. Their trail brought me north along the Narrows Road. The tracks showed that the pack frequently split and rejoined as they traveled along the roadway, and that individual wolves often stopped near rocks, piles of snow and trees, sniffing and leaving urine and scat marks.

The tracks continued along the Narrows Road for $5 \mathrm{~km}$, then left the road and went into the forest where all the wolf tracks aligned to follow a single trail. This is wellknown behaviour that allows the pack to save energy by using one individual to break trail through snow. After $500 \mathrm{~m}$, Nahanni stopped and started to whimper. There was a raven flying overhead and I smelled blood, wolf urine and scat. The wolf trail split 
several times and it was impossible to follow one wolf's track without intercepting the tracks of another.

Finally, I saw the carcass. A young, male moose had gotten wedged at its shoulders between two small spruce trees and was effectively pilloried. There are several alternative explanations for the situation. The moose may have gotten stuck accidentally and either starved to death or was killed by wolves that found it stuck. Or perhaps the moose had, in the heat of the chase by wolves, tried to pass between two trees and became physically stuck as it tried to move ahead or was so disoriented that backing-up was not considered. Whatever the circumstances, the 'geometry' of this kill, as a freak occurrence, is fascinating. (see Figure 1).

Based on the labyrinth of tracks, the fact that the carcass had been heavily consumed, and the forty wolf scats which I collected for dietary and genetic analysis, I speculate that the wolves spent at least two days at this site.

That same evening, I stopped again near the lake shore and waited, silent and motionless until dark. At 7:00 PM, the two groups of wolves started howling, each calling and answering the other. The wolves were only one $\mathrm{km}$ from where I had found the pilloried moose. Breathless, I listened for an hour and waited until silence.

\section{Acknowledgements}

Thanks to Bradley Muir for his help in preparing, editing and submitting this article, and to Gregg Rutten for his photograph. This work is part of Erin Urton's study of the dietary and genetic variation in Grey Wolves through the University of Saskatchewan.

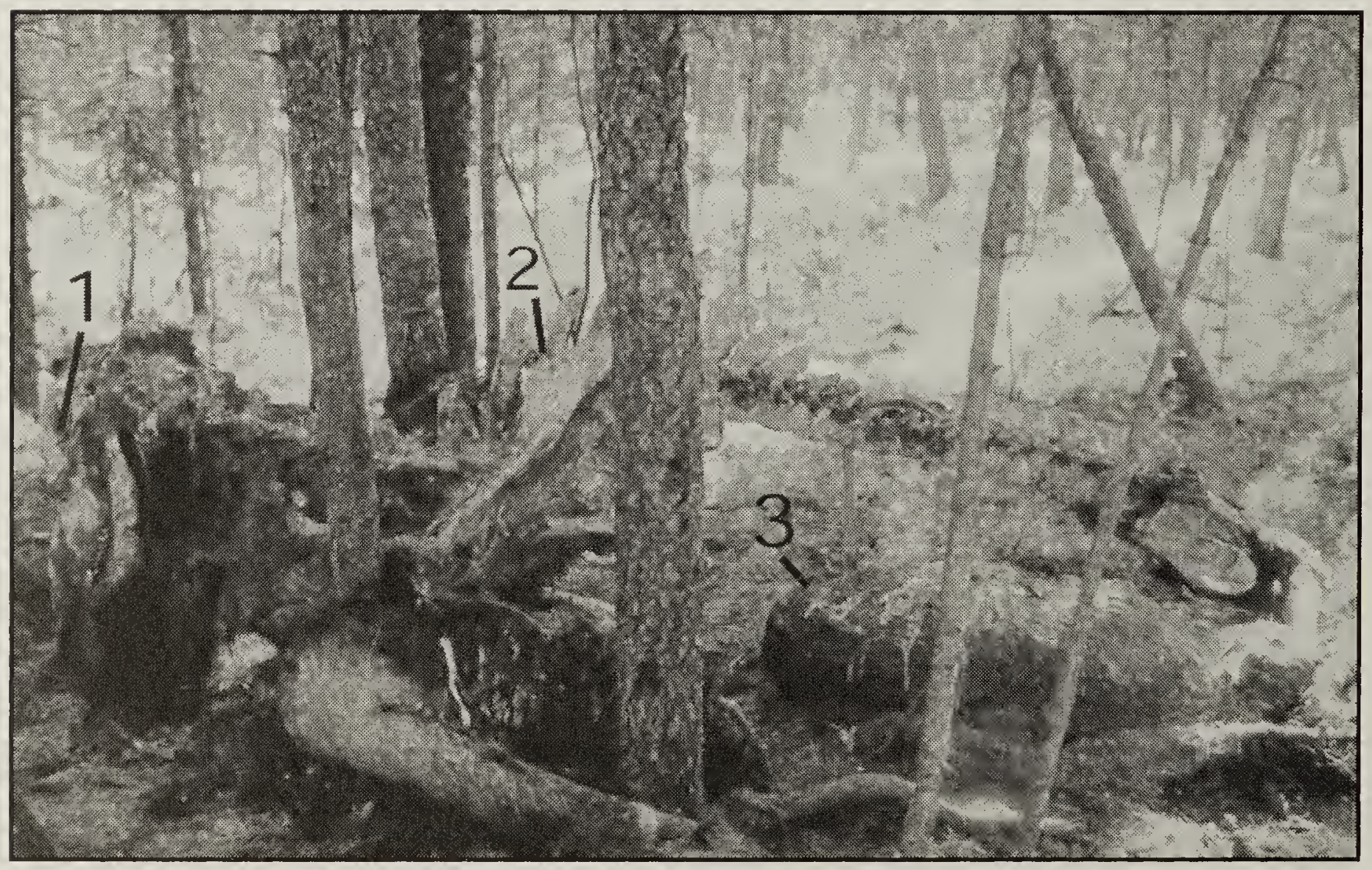

Figure 1: View of left side of carcass. 1. skull indicating left eye, 2. left scapula (shoulder blade), 3. frozen gut pile unconsumed by scavengers

Gregg Rutten 